\title{
OPTIMIZATION OF MICROWAVE-ASSISTED EXTRACTION OF THYMOQUINONE FROM NIGELLA SATIVA L. SEEDS
}

\author{
Erkan Karacabey \\ Food Engineering Department, Engineering Faculty, Suleyman Demirel University, \\ 32260, Isparta, Turkey \\ erkankaracabey@sdu.edu.tr
}

\begin{abstract}
The high potential of thymoquinone as an ingredient and/or additive in the food, pharmaceutical and cosmetic industries has been well established in previous studies. However, its extraction from natural sources was considered in the limited studies and none of them included the microwave-assisted extraction (MAE) of a thymoquinone-rich extract and process optimization. In the present study, this highvalue-added bioactive was aimed to extract from its well-known natural source, black cumin seed (Nigella sativa $\mathrm{L}$.), using methanol as a solvent for all of the studied extraction methods. For extraction of a compound of interest, microwave-assisted extraction system having temperature controlling function was used and its performance was compared with common extraction methods, Soxhlet and conventional solid/liquid extraction. The results indicated that the MAE system provided a rich extract containing thymoquinone, which was 2 and 7 times higher than those produced by conventional solid/liquid extraction and Soxhlet, respectively. Influences of temperature, time and solvent/solid ratio on thymoquinone yield were investigated for MAE. The solvent/solid ratio was found to have the main effect on extraction performance, whereas an interaction effect of temperature and time was significant. Variables of MAE were optimized by response surface methodology to produce a thymoquinone-rich extract. Optimal conditions for the highest yield of thymoquinone were determined as 10 minutes extraction at $30^{\circ} \mathrm{C}$, using 30 $\mathrm{ml}$ solvent per gram of black cumin seed. The estimated thymoquinone yield of the extract was 628 $\mathrm{mg} / \mathrm{kg}$ black cumin seed. It could be concluded that the currently optimized MAE with temperature controlling function is a promising technique to produce a thymoquinone-rich extract from black cumin seeds.
\end{abstract}

Keywords: black cumin seed; methanolic extract; response surface methodology; solvent/solid ratio

\section{ОПТИМИЗАЦИЈА НА ЕКСТРАКЦИЈА НА ТИМОХИНОН ОД СЕМЕ НА NIGELLA SATIVA L. ПОМОГНАТА СО МИКРОБРАНОВИ}

\footnotetext{
Високиот потенцијал на тимохинон како состојка и/или адитив во храната, во фармацевтската и козметичката индустрија е потврден во повеќе претходни истражувања. Меѓууоа, екстракцијата од природни извори е истражувана само во мал број студии, а во ниту една не е вршена екстракција со помош на микобранови (MAE) на екстракт богат со тимохинон, како ни оптимизација на процесот. Во ова истражување целта беше оваа високо вредна биоактивна супстанција да се екстрахира од добро познат природен извор - семето на црн ким (Nigella sativa L.), со употреба на метанол како растворувач за сите истражувани екстракциони методи. За екстракција на супстанцијата од интерес беше употребен системот МАЕ, кој овозможува контрола на температурата, и неговите перформанси беа споредени со вообичаени екстракциони методи: екстракцијата по Сокслет и цврсто/течната екстракција. Резултатите покажаа дека системот МАЕ дава збогатен екстракт што содржи, соодветно, 2 и 7 пати повеќе тимохинон во однос на конвенционалната цврсто/течна екстракција, односно екстракцијата по Сокслет. За МАЕ беше истражувано влијанието на температурата, времето и односот растворувач/цврста супстанција. Се
} 
утврди дека најголемо влијание врз екстракцијата има односот растворувач/цврста супстанција но и интеракциското влијание на температурата и времето беше значајно. Променливоста на MAE беше оптимизирана со методологијата на површински одговор за да се добие екстракт богат со тимохинон. Утврдено е дека оптималните услови за највисок принос на тимохинон се: време на екстракција од $10 \mathrm{~min}$ на температура од $30{ }^{\circ} \mathrm{C}$ со употреба на $30 \mathrm{ml}$ растворувач за еден грам семе од црн ким. Проценетиот принос на тимохинон изнесуваше $628 \mathrm{mg} / \mathrm{kg}$ семе од црн ким. Може да се заклучи дека оваа оптимизирана екстракција со помош на микробранови (MAE) со функција за контрола на температурата е техника која ветува добивање екстракт богат со тимохинон од семе на црн ким.

Клучни зборови: семе од црн ким; метанолен екстракт; методологија на површински одговор; однос растворувач/цврста супстанција

\section{INTRODUCTION}

Herbal origin recipes have been widely used treatments in folk therapies against various diseases since ancient times. There are many factors affecting the quality of these herbal medicines; most attention has been focused on sample preparation, target compounds, and analytical methods [1].

Black cumin (Nigella sativa L.), a good source of functional constitutes, has received increasing interest due in part to its healing effect against some diseases [2, 3], as well as improvements in the quality and stability of food formulations [4]. Solvent extracts, seeds and/or seed oils are the common forms of this herb which are used in treatments $[5,6]$. The therapeutic potential of herbs is partially related to their bioactive contents [7, 8]. Thymoquinone (Fig.1) the primary component in black cumin seed extracts, has been shown to be responsible for the biological activity of black cumin seeds $[9,10]$, and is responsible for most of the beneficial health effects associated with the seed, oil, volatiles and extracts [9-13]. Thus, thymoquinone reveals high potential for its use as an ingredient and/or additive in the food, pharmaceutical and cosmetic industries. In this regard, extraction of this bioactive from its natural source is significant. However, thymoquinone extraction from black cumin seeds has only been considered in limited studies [14-17], none of which focused on its methanolic extraction by microwave-assisted extraction (MAE). Kiralan et al. [18] investigated the influence of extraction methods including MAE on the physicochemical properties and stability of black cumin seed oil (Nigella sativa), but bioactives were out of the scope of that study. Additionally, there have been studies investigating the extraction of essential oils and volatiles from black cumin seed by microwave- and hydro-distillation, the results of which revealed that microwave-assisted distillation pro- vided a higher yield in shorter processing time with lower energy consumption [13, 19].<smiles>CC1=CC(=O)C(C(C)C)=CC1=O</smiles>

Fig. 1. Chemical structure of thymoquinone [9]

Microwave-assisted extraction (MAE) is well-established method that has recently been successfully applied for the separation of phytochemicals from plant sources [20]. MAE is regarded as a superior method with inherent advantages (simple application, reduction in process time and lower solvent usage) over traditional solvent/solid techniques [21], but most of the microwave-based systems do not have any temperature controlling function. However, equipment with a temperature controlling function may provide valuable information about the effect of temperature on the extraction performance and reproducible results may be achieved. Thus, extraction temperature should be monitored during the process and investigated as a factor affecting MAE alongside others such as process time [22], solvent system [20], microwave power level [23], and contact surface area [24].

Optimization of process variables with respect to interested response is significant, since any research work without optimization is not sufficient to adapt the same system to large scale applications. Response surface methodology (RSM) is a common tool used for process evaluation and optimization of interested factors, including information about individual factor effects and their interactions on studied responses and optimal conditions, depending on the desired purpose [25]. To the best of the author's 
knowledge, no information about optimized MAE of thymoquinone from black cumin seeds has been reported in the literature.

The main goal of the present study was to achieve high thymoquinone yield in an extract which was produced by methanolic extraction from black cumin seed. Also, extraction conditions were investigated to determine the change in yield of thymoquinone in extracts depending on these process conditions. Finally, the extraction parameters were optimized in order to achieve the highest yield of thymoquinone in extracts when using the response surface methodology.

\section{MATERIALS AND METHODS}

\subsection{Materials}

Black cumin seeds were supplied by a local producer in Turkey. Seeds were ground until the particle size was less than $500 \mu \mathrm{m}$ and stored at $4{ }^{\circ} \mathrm{C}$. Methanol (HPLC and analytical grade), acetic acid and authentic standard of thymoquinone were purchased from Sigma-Aldrich (St. Louis, MO, USA).

\subsection{Extraction of thymoquinone using conventional methods}

Soxhlet and conventional solvent/solid extractions were performed for the comparison of MAE performances in terms of target compound yield. A six-hour process was found to be long enough for Soxhlet extraction. Solvent/solid extraction was carried out as an overnight process with gentle stirring. Methanol is one of the most commonly used solvents in the literature for the successive extraction of thymoquinone from black cumin seeds [11, 16, 26, 27]. Another point is the solvent/solid ratio being significant on mass transfer taking place during the extraction process, as its higher value provides more effective mass transfer. As a result, pure methanol was used as an extraction solvent at a solvent/solid ratio of $40 \mathrm{ml} / \mathrm{g}$ black cumin seed for both methods. Extracts were stored in a freezer at $-18{ }^{\circ} \mathrm{C}$ until HPLC analysis.

\subsection{Microwave-assisted extraction (MAE) of thymoquinone}

MAE of thymoquinone from ground material was carried in a Milestone "Dry Dist" microwave reactor $2455 \mathrm{MHz}$ (DryDist, Milestone, Sorisole (BG), Italy) (Milestone s.r.l., Bergamo, Italy); the PTFE-coated cavity dimensions were $35 \mathrm{~cm} \times 35 \mathrm{~cm} \times 35 \mathrm{~cm}$. Analytical grade methanol was used as an extraction solvent for all trials. The experimental design for MAE of thymoquinone from black cumin seeds is given in Table 1 . The extraction procedure was carried out at atmospheric pressure at a constant temperature specified in the experimental design for each trial (Table 1). In a typical MAE procedure, a $5 \mathrm{~g}$ aliquot of ground black cumin seeds was placed into a $250 \mathrm{ml}$ round-bottomed flask; specified volume of pure methanol was added and waited for $15 \mathrm{~min}$ in a closed flask, before extraction.

Table 1

Experimental design and thymoquinone content of corresponding extract

\begin{tabular}{cccccc}
\hline \hline StdOrder & RunOrder & $\begin{array}{c}\text { Temperature } \\
\left({ }^{\circ} \mathrm{C}\right)\end{array}$ & $\begin{array}{c}\text { Time } \\
(\mathrm{min})\end{array}$ & $\begin{array}{c}\text { Solvent/Solid } \\
\text { ratio }(\mathrm{ml} / \mathrm{g})\end{array}$ & Thymoquinone $^{*}$ \\
\hline 3 & 1 & 30 & 40 & 20 & 473.52 \\
9 & 2 & 40 & 10 & 10 & 382.25 \\
5 & 3 & 30 & 25 & 10 & 411.11 \\
1 & 4 & 30 & 10 & 20 & 554.28 \\
6 & 5 & 50 & 25 & 10 & 407.19 \\
15 & 6 & 40 & 25 & 20 & 467.12 \\
7 & 7 & 30 & 25 & 30 & 516.04 \\
14 & 8 & 40 & 25 & 20 & 494.54 \\
2 & 9 & 50 & 10 & 20 & 393.04 \\
4 & 10 & 50 & 40 & 20 & 510.66 \\
13 & 11 & 40 & 25 & 20 & 498.82 \\
8 & 12 & 50 & 25 & 30 & 422.32 \\
12 & 13 & 40 & 40 & 30 & 415.52 \\
11 & 14 & 40 & 10 & 30 & 551.90 \\
10 & 15 & 40 & 40 & 10 & 442.02 \\
\hline \hline
\end{tabular}


${ }^{*}$ Target compound in extract was given as mg compound/kg seed

The temperature was monitored by an external IR sensor. The constant solvent quantity was guaranteed by the refluxing of condensed methanol, which was achieved by a circulating cooling system attached to the top of an extraction flask located in the center of the cavity, although the highest temperature level $\left(50{ }^{\circ} \mathrm{C}\right)$ specified in the experimental design was lower than the boiling point $\left(64.7^{\circ} \mathrm{C}\right)$ of methanol at atmospheric pressure. The calculated thymoquinone content is given as $\mathrm{mg}$ thymoquinone/kg black cumin seed in Table 1 .

\subsection{Analysis}

HPLC analysis was conducted to determine the thymoquinone content of black cumin seed extracts. UV detection analysis was carried out using a liquid chromatograph system (Agilent 1260 Infinity series, Agilent Technologies Inc., Palo Alto, CA, USA) equipped with a UV detector, a manual injector, and a control module. Extract was filtered through a $0.45 \mu \mathrm{m}$ membrane disk held in $25 \mathrm{~mm}$ diameter syringe filter holders (Millipore Corporation, Billerica, MA, Ireland) and subjected to HPLC analysis by injecting the sample into a reversed-phase C18 (Zorbax XDB, $5 \mu \mathrm{m}, 250 \mathrm{~mm}$ $\times 4.6 \mathrm{~mm}$, ID, Agilent Technologies Inc., Palo Alto, CA, USA) column. The isocratic mobile phase consisted of solvent (A) (3\% aqueous acetic acid) and solvent (B) (HPLC grade methanol) at a ratio of 30:70 $(\mathrm{v} / \mathrm{v})$. The flow rate of the mobile phase was $1.0 \mathrm{ml} / \mathrm{min}$. Thymoquinone (detection at $254 \mathrm{~nm}$ ) [28] was analyzed qualitatively comparing its retention time with an authentic standard. Thymoquinone content was calculated using its peak area and a standard curve.

\subsection{Experimental design}

MAE was optimized to achieve an extract with the highest thymoquinone content. Statistical methods and response surface methodology were used for this purpose. Independent variables were temperature (X1), time (X2), and solvent/solid ratio (X3). Studied levels of process variables were determined according to Box-Behnken design, where each variable was tested at 3 levels and the design was composed of 15 runs, including three replicates at central point (Table 1).

The Minitab Statistical Package Program (Minitab 16.2.3.0) (Minitab Inc., State College, PA, USA) was used to evaluate experimental data which were fitted to a second order polynomial regression model containing the coefficient of linear, quadratic, and two factor interaction effects as shown below (Eq.1):

$$
Y=\beta_{0}+\sum_{i=1}^{3} \beta_{i} X_{i}+\sum_{i=1}^{3} \beta_{i i} X_{i}^{2}+\sum_{i=1}^{2} \sum_{j=i+1}^{3} \beta_{i j} X_{i} X_{j}
$$

where $Y$ was thymoquinone content, $\beta_{0}$ was the constant coefficient, $\beta_{\mathrm{i}}$ was the linear coefficient (main effect), $\beta_{\text {ii }}$ was the quadratic coefficient, and $\beta_{\text {ii }}$ was the two factor interaction coefficient. The model adequacy was checked by evaluating the coefficient of determination $\left(R^{2}\right)$ and lack-of-fit value. Statistical significance of the model and model parameters were determined at $5 \%$ probability level $(\alpha=0.05)$. The response surface graphs of predicted values by model were plotted using Sigma Plot v. 8.02 (2002) (SPSS Inc., Chicago, IL).

\section{RESULTS AND DISCUSSION}

Production of thymoquinone-rich extract was main interest of present study due to its high valueadded properties. For this purpose, black cumin seeds were used since they are a natural source of the target compound $[10,11,16]$. Limited studies have reported thymoquinone extraction from black cumin seeds and none have covered the microwave-assisted extraction (MAE) technique with a temperature controller module. Extracts obtained by Soxhlet, conventional solid/liquid extraction and MAE were analyzed by a liquid chromatography system to determine their thymoquinone contents. Extracts obtained by Soxhlet and conventional solid/liquid extraction contained $82.96 \mathrm{mg}$ thymoquinone $/ \mathrm{kg}$ seed, and $286.50 \mathrm{mg}$ thymoquinone/kg seed, respectively. MAE, performed according to Box-Behnken design, produced extracts with a thymoquinone content varying from $353.04 \mathrm{mg}$ thymoquinone $/ \mathrm{kg}$ seed to $571.90 \mathrm{mg}$ thymoquinone $/ \mathrm{kg}$ seed depending on the process conditions. Rao et al. [16] reported comparable thymoquinone amounts in black cumin seed extract obtained by supercritical $\mathrm{CO}_{2}$. The thymoquinone yield in all extracts obtained by MAE was higher than that in the extracts produced by Soxhlet and conventional solid/liquid extractions methods, so it could be said that MAE was superior in terms of thymoquinone transition from black cumin seed at the studied ranges of variables in the present study.

\subsection{Effects of extraction conditions on thymoquinone content of extract}

Process variables of a MAE system with temperature control module were investigated to determine their influences on the transition of thymoquinone from black cumin seed to the sol- 
vent. Figure 2 displays the change in thymoquinone content of extracts with respect to temperature and solvent/solid ratio. There was an inverse relationship between thymoquinone extraction and process temperature. An increase in MAE temperature resulted in a decrease in thymoquinone content of extract. This effect was more apparent when a higher solvent/solid ratio was used. Response surface belonging to thymoquinone yield as a function of time and temperature is shown in Figure 3. It could be concluded that lower levels of both process parameters need to be employed to produce a thymoquinonerich extract. A decrease in the thymoquinone content of methanolic extract may be associated with the thermal conversion of this compound, which is favored by high temperature extractions. In the literature, this compound has been classified as a light- and heat-sensitive compound and it has been reported that exposure to light and heat induced the conversion of this compound [26, 29]. Time was also shown to have a negative effect on the thymoquinone content of extract throughout the whole studied temperature range. This could be attributed to the adverse thermal effect on this compound, since thermal sensitivity of any constituent is a result of the temperature-time process. Liu et al. [30] also reported that the extraction efficiency of thymoquinone decreased considerably especially after certain extraction. Time- and solvent/solid ratio-dependent changes in the thymoquinone content of extracts are shown in Figure 4. An increase in thymoquinone content over time was observed in the extraction processes performed using lower levels of solvent/solid ratio. This favorable time effect may be attributed to prolonged extraction which allows more thymoquinone transition to the extraction solvent, but it should be considered that even for the highest extraction time of $40 \mathrm{~min}$, the amount of extracted thymoquinone was less than that obtained in the extraction process at a higher solvent/solid ratio $(>20 \mathrm{ml} / \mathrm{g}$ seed) for shorter process times $(<30 \quad \mathrm{~min})$ (Fig.4). Thymoquinone yield was mainly affected by the solvent/solid ratio (Table 2). Increasing the solvent/solid ratio increased the thymoquinone yield in the MAE. Improvement in thymoquinone content with the increase of the solvent/solid ratio was not limitless. No further change in thymoquinone yield was observed when the solvent/solid ratio used in MAE exceeded $25 \mathrm{ml}$ solvent/g black seed (Fig. 2 and Fig. 4) The variation in thymoquinone yield with the change of the solvent/solid ratio is consistent with mass transfer principles.

The driving force during mass transfer within the solid is considered to be the concentration gradient, which was greater when a higher solvent/solid ratio was used [31]. In other words, by increasing solvent volume, the amount of target compound dissolved in total volume of solvent increased and when the system reached to equilibrium, higher amount of thymoquinone was achieved from same amount of ground black cumin seed compared to the extraction carried out using the lower solvent solid ratio.

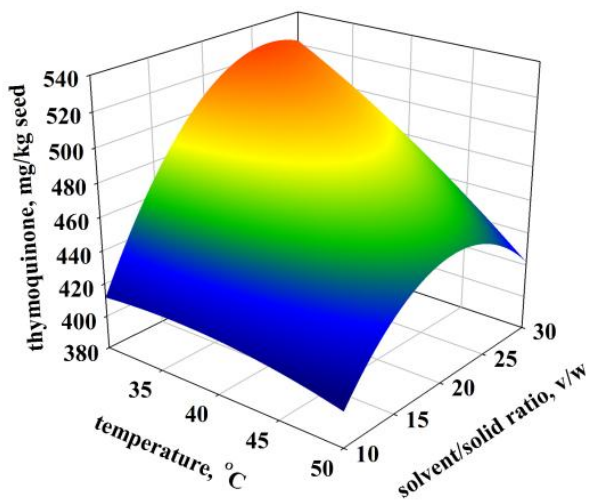

Fig. 2. Response surface of thymoquinone content of MAE extract as a function of the temperature and solvent/solid ratio.

A time of 25 min was the constant value in the model.

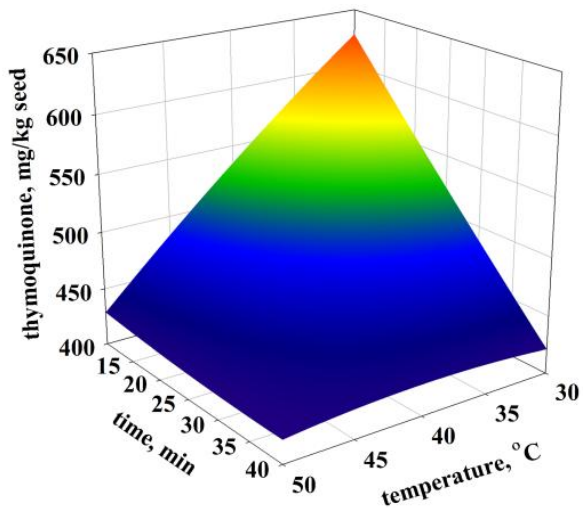

Fig. 3. Response surface of thymoquinone content of MAE extract as a function of time and temperature. A solvent/solid ratio of $20 \mathrm{ml} / \mathrm{g}$ was the constant value in the model. 


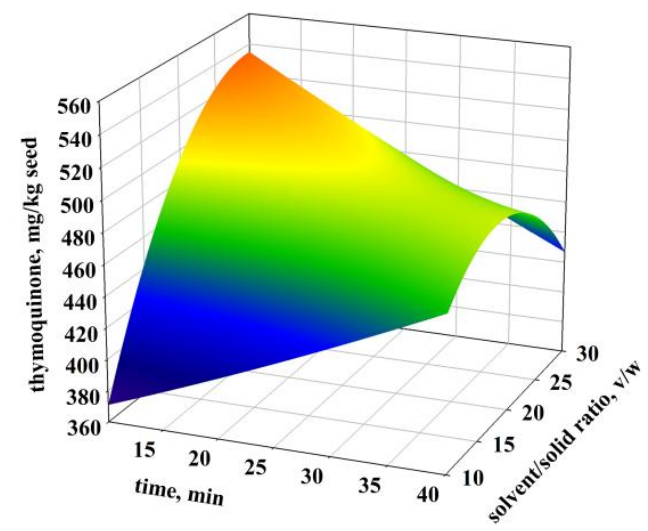

Fig. 4. Response surface of thymoquinone content of MAE extract as a function of time and solvent/solid ratio. A temperature of $40{ }^{\circ} \mathrm{C}$ was the constant value in the model.

Ta b le 2

ANOVA for response surface quadratic model: estimated regression model of relationship between response and independent variables $\left(X_{1}, X_{2}, X_{3}\right)$.

\begin{tabular}{llllll}
\hline \hline Source & Sum of squares & DF & Mean square & $F$-value & $p$-value \\
\hline Model & 42938.3 & 9 & 4770.9 & 10.13 & 0.100 \\
Linear & 18457.2 & 3 & 6152.4 & 13.06 & 0.008 \\
Quadratic & 6463.4 & 3 & 2154.5 & 4.57 & 0.068 \\
Cross-product & 21472.5 & 3 & 7157.5 & 15.19 & 0.006 \\
$\mathrm{X}_{1}$ & 11.2 & 1 & 11.2 & 0.02 & 0.884 \\
$\mathrm{X}_{2}$ & 1577.3 & 1 & 1577.3 & 3.35 & 0.127 \\
$\mathrm{X}_{3}$ & 14929.5 & 1 & 14929.5 & 31.69 & 0.002 \\
$\mathrm{X}_{1}{ }^{2}$ & 149.1 & 1 & 149.1 & 0.32 & 0.598 \\
$\mathrm{X}_{2}{ }^{2}$ & 21.3 & 1 & 21.3 & 0.05 & 0.840 \\
$\mathrm{X}_{3}$ & 6300 & 1 & 6300 & 13.37 & 0.015 \\
$\mathrm{X}_{1} \mathrm{X}_{2}$ & 9837.7 & 1 & 9837.7 & 20.88 & 0.006 \\
$\mathrm{X}_{1} \mathrm{X}_{3}$ & 2016.0 & 1 & 2016.0 & 4.28 & 0.093 \\
$\mathrm{X}_{2} \mathrm{X}_{3}$ & 9618.8 & 1 & 9618.8 & 20.42 & 0.006 \\
Lack-of-fit & 1763.9 & 3 & 588.0 & 1.99 & 0.352 \\
$R^{2}$ & 0.95 & & & & \\
$R_{\text {adj }}^{2}$ & 0.85 & & & & \\
\hline \hline
\end{tabular}

\subsection{Model fitting and process optimization}

Table 2 showed the results of fitting a second order polynomial regression model to the experimental data. The fitted model is given below (Eq. 2):

$$
\begin{array}{r}
y=267.51-1.46 X_{1}-7.55 X_{2}+36.97 X_{3}-0.06 X_{1}^{2} \\
+0.01 X_{2}^{2}-0.41 X_{3}^{2}+0.33 X_{1} X_{2}-0.23 X_{1} X_{3} \\
-0.33 X_{2} X_{3}
\end{array}
$$

The results of variance (ANOVA) for the full quadratic model developed to estimate thymoquinone content of black cumin seed extract as a function of temperature $\left(\mathrm{X}_{1}\right)$, time $\left(\mathrm{X}_{2}\right)$, and solvent/solid ratio $\left(\mathrm{X}_{3}\right)$ indicated that the prediction performance of the proposed model was good enough; the model adequacy parameters $\left(R^{2}, R_{a d j}^{2}\right.$, and lack-of-fit) were also found to be satisfying, as seen in Table 2. The results showed that the produced equation was able to explain $95 \%$ of the variance in experimental data. The model did not display any significant lack-of-fit $(p>0.05)$.

It could be seen that the variable with the largest effect on extraction yield of thymoquinone was the linear term of the solvent/solid ratio $\left(\mathrm{X}_{3}\right)$ followed by an interaction in terms of temperature and time $\left(\mathrm{X}_{1} \mathrm{X}_{2}\right)$ and time and solvent/solid ratio $\left(\mathrm{X}_{2} \mathrm{X}_{3}\right)$, and the quadratic term of the solvent/solid ratio $\left(\mathrm{X}_{3}^{2}\right)(p \leq 0.05)$ (Table 2). Linear and quadratic terms of temperature and time were not significant $(p>0.05)$. The main goal of the present study was to produce a thymoquinone-rich extract from black cumin seeds using an MAE system with temperature control, so process variables (temperature, time, and solvent solid ratio) were optimized using the developed full quadratic second order model. MAE performed at $30{ }^{\circ} \mathrm{C}$, for 10 minutes using $30 \mathrm{ml}$ solvent per gram of black cumin seed was found to be an optimized process providing the highest thymoquinone content of extract. 


\section{CONCLUSION}

In conclusion, the current study specifically reported the extraction of thymoquinone, which is a significant bioactive compound from black cumin seeds. Process parameters were investigated and their effects were assessed to determine their effects on the yield of thymoquinone in methanolic extract. For this purpose, MAE was proposed and compared with Soxhlet and conventional solvent solid extraction methods to show the effect of the MAE method. Process optimization was performed by response surface methodology in order to obtain an extract with the highest thymoquinone content. The results indicated that MAE is an alternative method for the extraction of thymoquinone from black cumin seed. The model prediction performance showed that response surface methodology is a useful tool for process optimization.

Acknowledgement. The author thanks Dr. Gülcan ÖZKAN and Dr. Seyhan ULUSOY for their valuable encouragement and support. Their technical assistance is also greatly appreciated.

\section{REFERENCES}

[1] Y. Pan, J. Zhang, T. Shen, Z.-T. Zuo, H. Jin, Y.-Z Wang, W.-Y. Li, Optimization of ultrasonic extraction by response surface methodology combined with ultrafast liquid chromatography-ultraviolet method for determination of four iridoids in Gentiana rigescens, $J$. Food Drug Anal. 23, 529-37 (2015).

DOI: http://dx.doi.org/10.1016/j.jfda.2014.11.002.

[2] J. D. Bewley, M. Black, P. Halmer. The Encyclopedia of Seeds: Science, Technology and Uses, CABI, 2006.

[3] Atta-ur-Rahman, S. Malik, H. Cun-heng, J. Clardy, Isolation and structure determination of nigellicine, a novel alkaloid from the seeds of Nigella sativa, Tetrahedron Let.t 26, 2759-62 (1985).

DOI: http://dx.doi.org/10.1016/S0040-4039(00)94904-9.

[4] M. Kiralan, M. Ulaş, A. Özaydin, N. Özdemır, G. Özkan, A. Bayrak, M. F. Ramadan, Blends of Cold Pressed Black Cumin Oil and Sunflower Oil with Improved Stability: A study based on changes in the levels of volatiles, tocopherols and thymoquinone during accelerated oxidation conditions, J. Food Biochem., n/an/a (2016). DOI: 10.1111/jfbc. 12272 .

[5] M. El-Dakhakhny, M. Barakat, M. Abd El-Halim, S. M. Aly, Effects of Nigella sativa oil on gastric secretion and ethanol induced ulcer in rats, J. Ethnopharmacol 72, 299-304 (2000).

DOI: http://dx.doi.org/10.1016/S0378-8741(00)00235-X.

[6] M. N. Nagi, M. A. Mansour, Protective effect of thymoquinone against doxorubicin-induced cardiotoxicity in rats: a possible mechanism of protection, Pharmacol. Res. 41, 283-9 (2000). DOI: http://dx.doi.org/10.1006/phrs.1999.0585.
[7] I. Hameed, G. Dastagir, F. Hussain, Nutritional and elemental analyses of some selected medicinal plants of the family Polygonaceae, Pak. J. Bot. 40, 2493-502 (2008).

[8] F. Jabeen, M. Shahbaz, M. Ashraf, Discriminating some prospective cultivars of maize (Zea mays L.) for drought tolerance using gas exchange characteristics and proline contents as physiological markers, Pak. J. Bot. 40, 2329-43 (2008).

[9] B. H. Ali, G. Blunden, Pharmacological and toxicological properties of Nigella sativa, Phytother. Res. 17, 299-305 (2003). DOI: 10.1002/ptr.1309.

[10] M. F. Ramadan, Nutritional value, functional properties and nutraceutical applications of black cumin (Nigella sativa L.): An overview, Int. J. Food Sci. Tech. 42, 120818 (2007). DOI: 10.1111/j.1365-2621.2006.01417.x.

[11] H. Lutterodt, M. Luther, M. Slavin, J.-J. Yin, J. Parry, J.M. Gao, L. Yu, Fatty acid profile, thymoquinone content, oxidative stability, and antioxidant properties of cold-pressed black cumin seed oils, LWT - Food Sci. Technol. 43, 1409-13 (2010). DOI: http://dx.doi.org/10.1016/j.lwt.2010.04.009.

[12] F. Benkaci-Ali, A. Baaliouamer, J. P. Wathelet, M. Marlier, Chemical composition and physicochemical characteristics of fixed oils from algerian Nigella sativa seeds, Chem. Nat. Compd. 47, 925-31 (2012). DOI: $10.1007 / \mathrm{s} 10600-012-0106-7$.

[13] F. Benkaci-Ali, R. Akloul, A. Boukenouche, E. D Pauw, Chemical composition of the essential oil of Nigella sativa seeds extracted by microwave steam distillation, Journal of Essential Oil Bearing Plants 16, 781-94 (2013). DOI: 10.1080/0972060X.2013.813275.

[14] N. Erkan, G. Ayranci, E. Ayranci, Antioxidant activities of rosemary (Rosmarinus officinalis L.) extract, blackseed (Nigella sativa L.) essential oil, carnosic acid, rosmarinic acid and sesamol, Food Chem. 110, 76-82 (2008).

DOI: http://dx.doi.org/10.1016/j.foodchem.2008.01.058.

[15] A. A. Mariod, R. M. Ibrahim, M. Ismail, N. Ismail, Antioxidant activity and phenolic content of phenolic rich fractions obtained from black cumin (Nigella sativa) seedcake, Food Chem. 116, 306-12 (2009). DOI: http://dx.doi.org/10.1016/j.foodchem.2009.02.051.

[16] M. V. Rao, A. H. Al-Marzouqi, F. S. Kaneez, S. S. Ashraf, A. Adem, Comparative evaluation of SFE and solvent extraction methods on the yield and composition of black seeds (Nigella Sativa), J. Liq. Chromatogr. Rel. Technol. 30, 2545-55 (2007). DOI: $10.1080 / 10826070701540100$.

[17] Z. Solati, B. S. Baharin, H. Bagheri, Supercritical carbon dioxide (SC-CO2) extraction of Nigella sativa $\mathrm{L}$. oil using full factorial design, Ind .Crop Prod. 36, 519-23 (2012). DOI: http://dx.doi.org/10.1016/j.indcrop.2011.11.004.

[18] M. Kiralan, G. Özkan, A. Bayrak, M. F. Ramadan, Physicochemical properties and stability of black cumin (Nigella sativa) seed oil as affected by different extraction methods, Ind. Crop Prod. 57, 52-8 (2014). DOI: http://dx.doi.org/10.1016/j.indcrop.2014.03.026.

[19] F. Benkaci-Ali, A. Baaliouamer, B. Y. Meklati, F. Chemat, Chemical composition of seed essential oils from Algerian Nigella sativa extracted by microwave 
and hydrodistillation, Flavour Fragrance $J$ 22, 148-53 (2007). DOI: $10.1002 / f f j .1773$

[20] W. Routray, V. Orsat, Microwave-assisted extraction of flavonoids: A review, Food Bioprocess Tech. 5, 409-24 (2012). DOI: 10.1007/s11947-011-0573-z.

[21] T. S. Ballard, P. Mallikarjunan, K. Zhou, S. O'Keefe, Microwave-assisted extraction of phenolic antioxidant compounds from peanut skins, Food Chem. 120, 1185-92 (2010).

DOI: http://dx.doi.org/10.1016/j.foodchem.2009.11.063.

[22] Y. Wang, J. You, Y. Yu, C. Qu, H. Zhang, L. Ding, H. Zhang, X. Li, Analysis of ginsenosides in Panax ginseng in high pressure microwave-assisted extraction, Food Chem. 110, 161-7 (2008).

DOI: http://dx.doi.org/10.1016/j.foodchem.2008.01.028.

[23] W. Ma, Y. Lu, X. Dai, R. Liu, R. Hu, Y. Pan, Determination of anti-tumor constitute mollugin from traditional Chinese medicine rubia cordifolia: Comparative study of classical and microwave extraction techniques, Sep. Sci. Technol. 44, 995-1006 (2009). DOI: 10.1080/01496390802691265.

[24] V. Kothari, S. Seshadri, Antioxidant activity of seed extracts of Annona squamosa and Carica papaya, Nutr. Food Sci. 40, 403-8 (2010). DOI: doi:10.1108/00346651011062050.

[25] R. H. Myers, D. C. Montgomery, C. M. Anderson-Cook. Response Surface Methodology: Process and Product Optimization Using Designed Experiments: Wiley, 2009.
[26] B. Avula, Y.-H. Wang, Z. Ali, I. A. Khan, Quantitative determination of chemical constituents from seeds of Nigella sativa L. using HPLC-UV and identification by LC-ESI-TOF, J AOAC Int. 93, 1778-87 (2010).

[27] S. Bourgou, R. Ksouri, A. Bellila, I. Skandrani, H. Falleh, B. Marzouk, Phenolic composition and biological activities of Tunisian Nigella sativa $\mathrm{L}$. shoots and roots, C. R. Biol. 331, 48-55 (2008). DOI: http://dx.doi.org/10.1016/j.crvi.2007.11.001.

[28] O. A. Ghosheh, A. A. Houdi, P. A. Crooks, High performance liquid chromatographic analysis of the pharmacologically active quinones and related compounds in the oil of the black seed (Nigella sativa L.), $J$. Pharm. Biomed. Anal. 19, 757-62 (1999). DOI: http://dx.doi.org/10.1016/S0731-7085(98)00300-8.

[29] L. I. Smith, R. W. H. Tess, Dithymoquinone, J. Am. Chem. Soc. 66, 1323-5 (1944). DOI: $10.1021 / \mathrm{ja} 01236 \mathrm{a} 036$.

[30] X. Liu, J.-H. Park, A. M. Abd El-Aty, M. E. Assayed, M. Shimoda, J.-H. Shim, Isolation of volatiles from Nigella sativa seeds using microwave-assisted extraction: effect of whole extracts on canine and murine CYP1A, Biomed. Chromatogr. 27, 938-45 (2013). DOI: $10.1002 / \mathrm{bmc} .2887$.

[31] J. E. Cacace, G. Mazza, Mass transfer process during extraction of phenolic compounds from milled berries, $J$ Food Eng. 59, 379-89 (2003).

DOI: http://dx.doi.org/10.1016/S0260-8774(02)00497-1. 